\title{
Effects of the Decision-Making Process on the Competitive Advantage in Costs Obtained After Implementing Outsourcing
}

\author{
Henrique de Castro Neves ${ }^{1}$, José Carlos de Souza Colares ${ }^{2}$, João Bosco Favero ${ }^{3}$, Jean Carlo Silva dos $\operatorname{Santos}^{4} \&$ \\ Rosangela Aparecida da Silva ${ }^{5}$ \\ ${ }^{1}$ Business Administration, Universidad Nacional de La Matanza, Buenos Aires, Argentina \\ ${ }^{2}$ Public Finance and State Administration, Universidad Nacional de La Matanza, Buenos Aires, Argentina \\ ${ }^{3}$ Public Administration, Universidad Nacional de La Matanza, Argentina \\ ${ }^{4}$ UFRGS-EA, Brazil \\ ${ }^{5}$ Faculdade União das Escolas Superiores de Rondônia, UNIRON, Brazil \\ Correspondence: Henrique de Castro Neves, Postgraduate Program in Economic Sciences, Business Administration, \\ Universidad Nacional de La Matanza, Buenos Aires, Argentina.
}

Received: July 29, 2021

doi:10.5430/ijba.v12n5p33
Accepted: September 3, 2021

Online Published: September 15, 2021

\begin{abstract}
This article aims to answer how the decision process model used to adjudicate on the implementation of outsourcing in the company affected the competitive advantage in costs obtained by the organization after the implementation of subcontracting. Therefore, the financial results obtained by the company in the period from 2015 to 2019 were analysed in order to know if there were competitive advantages in costs arising from the decision to implement outsourcing. Studies were also carried out on the structure of the decision-making process adopted by the entity to identify the level of efficiency of this model in the implementation of outsourcing, and finally, the impacts generated on these advantages due to the degree of efficiency of the tool application were verified. The research strategy was qualitative and quantitative, with an exploratory bias, bibliographic survey and structured interview. A mathematical model was used based on 14 (fourteen) decision-making efficiency indicators, 4 (four) efficiency level classification indicators and 5 (five) classification criteria for performance. The results showed that there is sufficient evidence to conclude that the low level of efficiency in the decision-making structure contributed to the high financial impact on Company Alpha and, consequently, to the negative impact on competitiveness acquired through the implementation of outsourcing in this entity, which caused financial disadvantages represented by losses in operating income and reduction in profitability.
\end{abstract}

Keywords: decision making process, outsourcing, competitive advantage, efficiency

\section{Introduction}

Business efficiency will always be a consequence of the managers' incessant search for the best possible economic results, to be obtained through the management of existing resources, among which are the people in charge of putting into practice the activities and tasks that result in the production of goods and services intended to remunerate the capital invested in the business through marketing.

Therefore, business administrators must be concerned with dealing with the problems that affect the organization's economic and financial performance. There are several tools, such as cost management, sales forecasting, quality control, productivity, customer management, procurement and training, among others, which form the apparatus of methods and tools designed to support executives in the enterprise's management process.

In this universe of methods, there is the decision-making system, which represents a human and behavioural action that comprises the choice, consciously or not, of certain actions among those available, which will affect behaviours and attitudes aimed at achieving the desired results.

In this sense, the decision-making process presents itself as an important strategic tool to support business management. Therefore, it is necessary that organizations have a properly structured system in order to allow the 
reduction of errors resulting from the numerous decisions taken daily and, thus, mitigate the losses arising from wrong decisions.

This paper analyses and discusses the impacts of the decision-making process with regard to the competitive advantage in costs obtained from the implementation of the outsourcing process in a Brazilian company. The intention is to know the consequences of these advantages due to the degree of efficiency of the decision-making model adopted in the organization.

\section{Research Problem and Objectives}

In this work, the fundamental problem is to analyse the structure of the organization's decision-making process in order to understand how this procedure affects the competitive advantage in costs obtained by the company after the implementation of outsourcing. The intention is to clarify whether the techniques used by the enterprise for decision-making regarding the decision to implement the outsourcing of production and services, contributed or hindered the cost advantages gained after adopting outsourcing. Thus, as the main basis of this study, the following question is proposed: What are the effects of the decision-making process on the competitive cost advantage obtained by the company after the implementation of the outsourcing of production and services in the organization?

To respond to this question, it is proposed as a general objective to identify the impacts on the competitive advantage in costs obtained after the implementation of outsourcing, due to the level of efficiency of the decision-making structure used to decide on implementing the practice of outsourcing in the company. As specific objectives, it is proposed: (a) to identify the company's financial results in order to know which competitive advantages in costs were acquired after the outsourcing implementation; (b) to study the structure of the decision-making process adopted by the researched organization, in order to identify the efficiency level of the model that was the basis for the decision to implement outsourcing in the company; and (c) to present the impacts generated on the competitive advantage in costs due to the efficiency or inefficiency of the decision-making process used.

\section{Theoretical Review}

The exposition of concepts on the subject of this research is the object discussed in this item. The information entered here is intended to provide support for the construct of this research. Thus, in this topic, information about decision-making models and their advantages, disadvantages, critical success factors, risks, legal requirements and controversies are addressed. Concepts and discussions on obtaining competitive cost advantages from the implementation of outsourcing are also presented, in order to identify how the decision-making process influences the financial results obtained from the implementation of this model.

\subsection{Decision-Making Process}

According to Chaves, Almeida and Borba (2020), a structured decision-making process aims to reduce the mistakes made by managers and enable the decisions taken to be the best possible. For the authors, errors can be minimized by organizing a systematic process that involves at least five steps, namely: problem identification, enumeration of possible solutions, the most suitable solution, practical implementation of the selected alternative and effective feedback aimed at responding within the appropriate period if the solution adopted was in fact the best path. For them, by properly identifying the problem and its causes and consequences, decision makers will be able to put in place efficient procedures to evaluate the proposals and ideas that prove viable to face the demand. The success in the process of choosing the most beneficial solution is that it will be able to demonstrate whether or not the results were satisfactory.

Navarro (2019), based on the studies by Orasanu and Connolly, addresses an interesting aspect about the decision-making process: naturalistic decision-making. According to the author, the elements that make up the environment that make up naturalistic decision making is formed by the pressure of time, the high level of risks, the expertise of decision makers, the level of adequacy of information (whether correct or wrong), the improper definition of objectives, poor definition of procedures, learning by suggestion (based on guesswork), the environmental context, the dynamics of the environment and the organization, and the level of team coordination capacity. For the author, the ultimate goal of any decision-making process is to find ways to avoid risks and, not being able to minimize them.

Matos and Back (2018) quoting Simon emphasize that the decision is nothing more than a procedure where available proposals regarding the course of an action to be followed are analysed. In this sense, the components of the decision-making process are pointed out, namely: the decision maker, in charge of choosing the option among the proposed alternatives; the decision objectives, which correspond to what the decision maker intends to achieve with 
his choice; preferences, which represent the criteria that the decision maker uses to select the proposal; the strategy, demonstrated by the actions to be taken so that the objectives are achieved; aspects of the organizational environment, which involve direct and indirect (non-controllable) variables that permeate the institution and affect choice; and, finally, the result, which is the product resulting from the choice made by the decision maker, where it can be verified whether the decision was adequate or not.

The decision-making process is one of the most relevant strategic tools in the management of companies, however, it is clear that this instrument is little used by managers. In general, entrepreneurs tend to make decisions predominantly based on experience and intuition, which ends up generating decisions that are not always consistent with the best choice. As an uncountable number of decisions are taken daily, there is a risk that organizations suffer losses and losses not accounted for (hidden costs) since the procedure may not be being properly controlled. It is noteworthy that a perfect decision is not expected, however the existence of a properly structured decision-making process is an essential condition to minimize the possibility of errors caused by wrong decisions (BERTONCINI et al, 2013).

Franz and Kramer (2010) inform that the decision-making process can be seen from two perspectives: the descriptive and the prescriptive model. From a descriptive perspective, events are deeply researched so that rich subsidies, motivations and circumstances for decision-making are offered. This model is guided by the behavioural theory that seeks to explain the actions of decision makers through empirical research where it seeks to isolate the behaviours of interest to the investigator. From a prescriptive point of view, the system is formatted to prescribe guidelines designed to guide the decision-making process. The prescriptive models are aligned with the Classical Theory of unlimited rationality and are linked to the exact sciences, with the issues of the dynamic reality that affect organizations and managers not being very important, what matters is defining and prescribing what should be done.

For the purposes of this research, in order to outline a decision model that can support the choice to adopt the outsourcing of services and production, it uses the decision-making structure proposed by Uris (1989), complemented by Maximiano (2009). Adding the proposals of these authors, it is suggested that a decision-making model would be adequate if it minimally considered the following items: (1) identification and diagnosis of problems; (2) construction of problem solving and alternatives; (3) analysis and evaluation of alternatives; (4) process of choosing the best alternative; (5) communication of vertical and horizontal options; (6) strategic decision; (7) long-term strategic thinking; (8) previous study of the infrastructure; (9) identification of the costs of the outsourcing process; (10) mapping of internal and external processes; (11) identification of internal and external benefits; (12) relationship between partner selection and desired competencies; (13) adequacy of service level; and (14) definition of areas subject to outsourcing.

\subsection{Competitive Advantage in Costs}

Sanches et al (2018), citing Martins, Hansen and Mowne, comments that cost competitive advantage is a strategy model designed to integrate two macroprocesses: cost management and business management. This integration aims to improve the understanding of production processes and their costs incurred, in order to use efficiently structured cost information to identify and develop sufficient strategies to produce competitive advantage over competitors. In this way, the cost advantage is obtained from continuous performance improvement and supported by an effective decision-making model that can surpass traditional cost management models.

One of the ways to reduce costs is through innovation. In this sense, innovation can provide cost savings, gains in quality and productivity, boost sales and improve operational management. In the specific case of cost reduction, innovation has the potential to enable competitive differentiation in relation to the competition. Innovative actions may provide the emergence of new services or products and new marketing approaches. These actions generally stem from small ideas that require low investment and, therefore, allow for greater profits. Thus, the organization can acquire a competitive advantage in costs, generating greater economic value than the competition, since the customer will be able to perceive greater benefit in relation to the total economic cost of the purchased product, surpassing the benefit generated by the competition, as prescribed by Turra, Mioranza and Coltre (2017).

Competitive advantage is acquired with the correct definition of the strategy to be followed. Porter (2005) points out that strategy is related to the creation of a management model capable of generating an exclusive high-value position that involves a variable set of activities. Thus, the strategy consists of an integrated plan of goals, policies and action plans of a company with the objective of achieving common and satisfactory results.

One of the ways to obtain a competitive advantage in costs is the transformation of fixed costs into variable costs, using the technique of outsourcing service and production (in part or total). In this process, the amounts of fixed 
expenses of a given company are replaced by expenses that increase or decrease in proportion to the demand, enabling the organization to obtain gains and advantages in costs in its management (NEVES and MARTINS, 2012). The subject is of vital importance for this work, as it is intended to investigate the impacts of the decision-making process on these advantages.

\subsection{Converting Fixed Costs Into Variable Costs Through Outsourcing}

Regarding the costs, it is known that, by definition, fixed costs are those expenses related to the operation that occur regardless of the quantity produced, that is, the disbursement must take place whether or not the goods were produced in a given establishment. Therefore, it can be concluded that the greater the production, the smaller the share of fixed costs in the unit cost of production. Variable costs, on the other hand, are defined as those related to the operation, that is, they vary directly with the variation in production. Thus, fixed costs fluctuate in time intervals much higher than variable costs, as, in addition to not following revenue linearly, fixed costs "scale up" each time the company makes an investment to support projected growth (MARTINS, 2010).

The transformation of fixed costs into variable costs is aimed at reducing operating costs and maximizing productivity. The main purpose of this conversion is to obtain a competitive advantage in costs with the maximization of the company's profitability and operating result, which can be achieved through the practice of outsourcing. The graphic below demonstrates the difference between the two types of costs under discussion (MCIVOR, 2005; JÚNIOR and PIRES, 2017; LEONE, 2005).
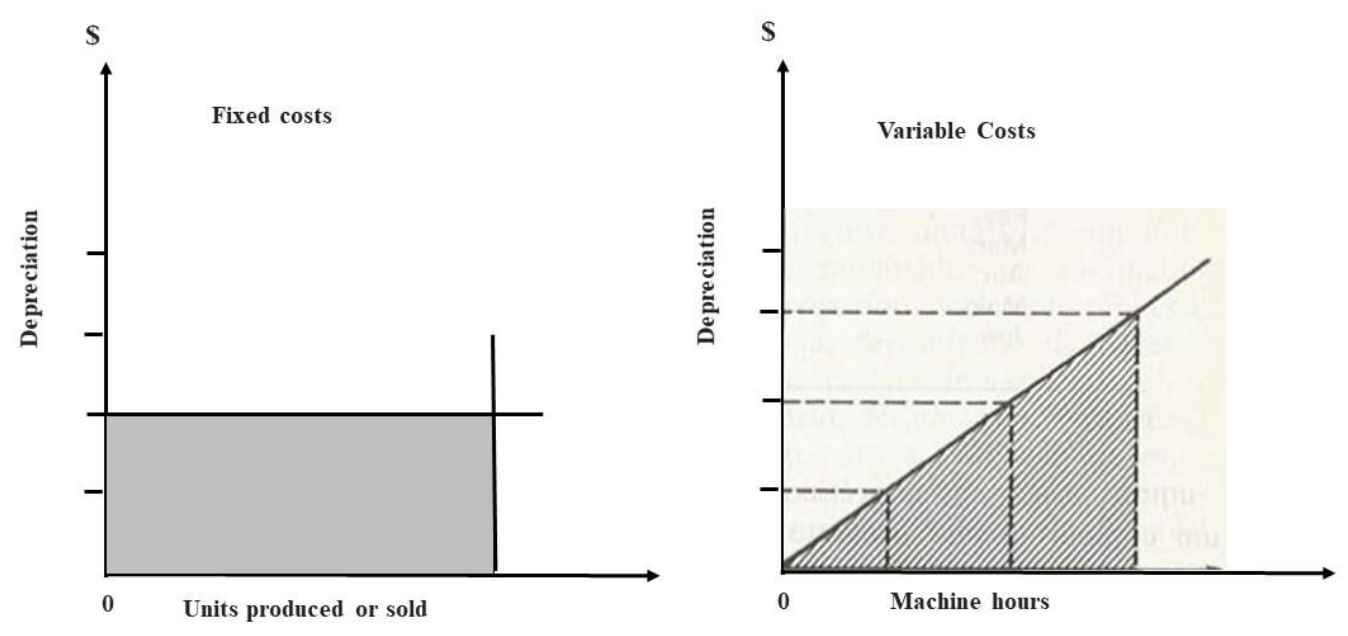

Figure 1. Fixed and variable cost chart

Source: Leone (2005), adapted.

With regard to subcontracting or outsourcing, according to McIvor (2005) it is a practice of provision or realization of products and services that were previously produced internally by the company using its own labour and resources and, later, started to be carried out by labour and external resources. In Brazil, this type of operation is called externalization, defined by the author as a management model that enables the delegation of responsibilities for the operationalization and management of production by specialized external agents, with the mission of undertaking greater efficiency in production processes, generating savings in resources compared to the traditional model of own production.

As main advantages, outsourcing allows greater concentration on the strategic vision of the business; cost reduction; process simplification; maximizing production capacity through the use of resources available from third parties; better use of the organization's staff time and effort; availability of a specialized supplier for the required activity; reduction and/or minimization of technical incompetence (VALENÇA and BARBOSA, 2002).

Among the advantages of applying outsourcing are: the dilution of direct and indirect costs (fixed and variable), the rationalization of resources, the re-engineering of its operations, the possibility of streamlining the business structure and organizational flexibility. No less important is the fact that outsourcing is an instrument to help the company's 
restructuring, the growth of its productivity and the strengthening of its competitiveness, which contributes to its survival in the market (SÁ, BOMTEMPO and QUENTAL, 1998).

As disadvantages, the model can lead to a possible loss of management control and potential quality problems, once the responsibility will pass to the partner. This will require a more robust and efficient monitoring modality by the contractor. Another situation with the possibility of disadvantage is the appearance of additional costs, motivated by failures or gaps in the contracts, which can give rise to opportunistic behaviour by the contractor. The threat to the security and confidentiality of strategic information and even intellectual property is another possible disadvantage of outsourcing, which can compromise the company's industrial secrets of restricted interest (ROCCO, 2020). Despite this, the outsourcing process always offers more advantages than disadvantages, it is only necessary that companies take due care in partner selection and in the preparation of contracts in order to avoid subcontracting inexperienced people or those unable to meet the demand, as well as avoid contractual spaces from which opportunistic demands may arise (FARIA, 1994; FREITAS, ALMEIDA and OLIVEIRA, 2017).

According to Mcivor (2005), for there to be the possibility of converting fixed costs into variables, it is fundamentally necessary that two situations converge: the decision to use outsourcing as a management model (in whole, in part, in some process or even some specific department); and a perfect identification of the fixed costs that one wants to transform into variable ones. Thus, when defining the application of outsourcing, the company must properly decide on its form of implementation.

\section{Methodology Applied in This Research}

The investigation was realized in a company located in the city of Juiz de Fora, State of Minas Gerais, Brazil. This company operates in the industrial segment and its branch of activities is the production of pieces for handcrafted furniture. The entity has operated for 10 years in the market and in 2019 it had an average of 74 employees. The work of investigating the data was carried out through on-site and virtual research, in addition to the examination of the financial statements considering the financial years 2015 to 2019. It is hereby informed that authorization was not received for the disclosure of the official name of the investigated company, therefore, a commitment was made to maintain the confidentiality of the information and the name of the researched organization. In view of this, it was agreed to name the organization by the nickname "Company Alpha".

As research strategy, a study was conducted in which real qualitative and quantitative data collection was used with purpose of examining and detail the observed phenomena with the aim to specify the researched object in order to deepen its understanding. This research is in the descriptive research class with a quantitative approach. Thus, the methodological triangulation was applied based on the combined and sequential use of the two phases, quantitative and qualitative, in order to overcome the limitations and provide greater robustness in the results of this thesis. It is also noteworthy that the research has an exploratory bias, as it seeks to highlight the problem through a literature review and makes use of interviews with the target audience, seeking to describe the characteristics of the phenomenon researched using of a structured questionnaire, with the objective of methodically discovering the knowledge of a problem still little known within a given situation (YIN, 2005; GIL, 2007).

For data collection, an instrument consisting of 14 (fourteen) variables was used to compose the efficiency indicators of the decision-making structure - iTEEPD and 4 (four) indicators and 5 (five) criteria for the formation of the Efficiency Rate. The elements are presented below.

a) Calculation of the efficiency index of the decision-making structure - iTEEPD: The objective is to find the efficiency index of the decision-making structure and the respective rates of the 14 (fourteen) efficiency indicators, where:

$$
\begin{aligned}
& i \text { TEEPD }=i E I d p+i E C s p a+i E A a a+i E P e m a+i E C o v h+i E d e e+i E P e l p+i E E p i ~+i E i c p o+i E M p i e \\
& +\mathrm{iEIbie}+\mathrm{iERspcd}+\mathrm{iEAns}+\mathrm{iEDapt}
\end{aligned}
$$

The efficiency index of the decision-making structure is the arithmetic mean of the 14 (fourteen) analysed indices, represented by the following equation:

$$
i T E E P D=\sum_{q=1}^{14} i q / 14
$$

Where:

-iTEEPD: Efficiency index of the decision-making structure. 
-iEIdp: Rate of problem identification and diagnosis efficiency.

- iECspa: Rate of problem solving and alternative construction efficiency.

-iEAaa: Rate of analysis efficiency and evaluation of alternatives.

-iEPema: Rate of process efficiency of choosing the best alternative.

-iECovh: Rate of efficiency of vertical and horizontal options communication.

-iEdee: Rate of strategic decision efficiency.

-iEPelp: Rate of long-term strategic thinking efficiency.

-iEEpi: Rate of infrastructure preliminary study efficiency.

-iEicpo: Rate of outsourcing process cost identification efficiency.

-iEMpie: Rate of mapping efficiency of internal and external processes.

-iEIbie: Rate of identification efficiency of internal and external benefits.

-iERspcd: Rate of the relationship efficiency between the selection of partners and the desired competencies.

-iEAns: Rate of efficiency of adequacy of the service level.

-iEDapt: Rate of efficiency in defining areas subject to subcontracting.

The Efficiency Rate was based on an instrument consisting of 4 (four) indicators and 5 (five) classification criteria as shown in the table below:

Table 1. Formation of the efficiency indicator rate

\begin{tabular}{ll}
\hline $\begin{array}{c}\text { Performance } \\
\text { Indicator }\end{array}$ & \multicolumn{1}{c}{ Investigated Question } \\
\hline 1. Application & $\begin{array}{l}\text { Verification if the company applies } \\
\text { the procedure. }\end{array}$ \\
\hline 2. Documentation & $\begin{array}{l}\text { Presentation of documentation or } \\
\text { any evidence that proves that the } \\
\text { company applies the procedure. }\end{array}$ \\
\hline
\end{tabular}

Analysis of the documentation presented to verify whether there

3. Documentation are sufficient elements to prove that validation the procedure is applied and that the results shown have evidence to confirm its veracity.

Presentation of the results obtained through the application of the procedure (reports that indicate 4. Results which results were achieved; which
Classification criteria and negative impact on financial results

\begin{tabular}{lcc}
\hline $\begin{array}{l}\text { Efficiency Rate } \\
\text { Interval }\end{array}$ & $\begin{array}{c}\text { Classificatio } \\
\mathrm{n} \text { criteria }\end{array}$ & $\begin{array}{c}\text { Impact on } \\
\text { financial } \\
\text { results }\end{array}$ \\
\hline From 1 to 1,50 & Very Low & Very low \\
\hline $\begin{array}{l}\text { From } 1,51 \text { to } \\
2,50\end{array}$ & Low & Low \\
\hline $\begin{array}{l}\text { From } 2,51 \text { to } \\
3,25\end{array}$ & Medium & Medium \\
\hline $\begin{array}{l}\text { from } 3,25 \text { to } \\
4,25\end{array}$ & High & High \\
\hline $\begin{array}{l}\text { From } 4,26 \text { to } \\
5,00\end{array}$ & Very High & Very high \\
\hline
\end{tabular}
risks were avoided; which losses and/or damages were avoided or minimized).

Source: Constructed by the authors from the literature used in the research. 
Thus, the Efficiency Rate Indicator matrix is composed as follows:

$$
i E X_{D}=\frac{A_{\text {ind }}+D_{\text {ind }}+V_{\text {ind }}+R_{\text {ind }}}{4}
$$

The Efficiency Rate Indicator is the arithmetic average of the 4 (four) analysed indicators.

Being:

iE: Efficiency rate indicator.

XD: Description of the dimension being analysed.

Aind: Indicator of the application description;

Dind: Indicator of used documentation;

Vind: Indicator of documentation validation.

Rind: Indicator of results.

To calculate the Rate of Impact on Financial Results, the efficiency indication rate indicators listed in Table 1 and the result of the Efficiency Rate Indicator (iEXD) are used, in the following mathematical composition:

$$
i I R F=\frac{1}{i E X_{D}}
$$

The Rate of Management Impact is inversely proportional to the Efficiency Rate Indicator, that is, the lower the efficiency index (iEXD), the greater the Impact,

Being:

IIRF: Rate of management impact.

iE: Efficiency rate indicator;

$\mathrm{X}_{\mathrm{D}}$ : Description of the dimension being analysed.

Once the 14 (fourteen) indexes related to the decision-making efficiency indicators were consolidated, the Microsoft Excel application was used to transport the data using the proposed mathematical model, in order to visualize the impacts on the results individually and collectively, as shown in the matrix below:

\begin{tabular}{|c|c|c|c|c|c|c|c|c|c|}
\hline $\begin{array}{c}\text { Rate } \\
\text { Description }\end{array}$ & $=$ & Application & $*$ & Documentation & $*$ & $\begin{array}{c}\text { Documentation } \\
\text { Validation }\end{array}$ & $*$ & Results & $\begin{array}{l}\text { Index of Negative } \\
\text { Impact on financial } \\
\text { results }\end{array}$ \\
\hline iEIdp & $=$ & EAidp & $*$ & EDidp & $*$ & EVidp & $*$ & ERidp & iIRF \\
\hline iECspa & $=$ & EAcspa & $*$ & EDcspa & $*$ & EVcspa & * & ERcspa & iIRF \\
\hline iEAaa & $=$ & EAaаa & $*$ & EDaaa & $*$ & EVaaa & $*$ & ERaaa & iIRF \\
\hline iEPema & $=$ & EApema & $*$ & EDpema & $*$ & EVpema & $*$ & ERpema & iIRF \\
\hline iECovh & $=$ & EAcovh & $*$ & EDcovh & $*$ & EVcovh & $*$ & ERcovh & iIRF \\
\hline iEdee & $=$ & EAdee & $*$ & EDdee & $*$ & EVdee & $*$ & ERdee & iIRF \\
\hline iEPelp & $=$ & EApelp & $*$ & EDpelp & $*$ & EVpelp & $*$ & ERpelp & iIRF \\
\hline iEEpi & $=$ & EAepi & $*$ & EDepi & $*$ & EVepi & $*$ & ERepi & iIRF \\
\hline iEicpo & $=$ & EAicpo & $*$ & EDicpo & $*$ & EVicpo & $*$ & ERicpo & iIRF \\
\hline iEMpie & $=$ & EAmpie & $*$ & EDmpie & $*$ & EVmpie & $*$ & ERmpie & iIRF \\
\hline iEIbie & $=$ & EAibie & $*$ & EDibie & $*$ & EVibie & $*$ & ERibie & iIRF \\
\hline iERspcd & $=$ & EArspcd & $*$ & EDrspcd & $*$ & EVrspcd & $*$ & ERrspcd & iIRF \\
\hline iEAns & $=$ & EAans & $*$ & EDans & $*$ & EVans & $*$ & ERans & iIRF \\
\hline
\end{tabular}

Table 2. Matrix of impact on financial results - Decision-making structure 


\begin{tabular}{clllllllll}
\hline iEDapt & $=$ & EAdapt & $*$ & EDdapt & $*$ & EVdapt & $*$ & ERdapt & iIRF \\
\hline TOTAL & $=$ & iETAepd & $*$ & iETDepd & $*$ & iETVepd & $*$ & iETRepd & iTIRFepd \\
\hline
\end{tabular}

Source: Constructed by the authors from the literature used in the research.

Where:

iE: Efficiency Rate Indicator.

E: Efficiency.

iET: Index of Total Efficiency.

iIRF: Rate of Management Impact.

$$
\begin{aligned}
& \text { EAidp }+ \text { EAcspa }+ \text { EAaaa }+ \text { EApema }+ \text { EAcovh }+ \text { EAdee }+ \text { EApelp }+ \\
& \text { EAepi }+ \text { EAicpo }+ \text { EAmpie }+ \text { EAibie }+ \text { EArspcd }+ \text { EAans }+ \text { EAdapt }
\end{aligned}
$$

iETAepd - Index of Total Efficiency of the Decision-Making Application Indicator: Corresponds to the efficiency index in relation to the application of the decision-making process: It is represented by the arithmetic average of the application of the 14 (fourteen) analysed indicators, as formulated above.

From a qualitative point of view, the structure of the decision-making process for outsourcing was examined, in addition to the Profit and Loses (P\&L) of each year for the period 2015 to 2019. The purpose was to verify whether the model contributed in any way to the impacts on profitability and in the company's operating results. The results are shown in the following topic.

\section{Results and Discussions}

In analysing the documents presented, it was noted that the Company Alfa adopted the outsourcing process and the transformation of fixed costs into variable costs as of 2015. In that year, the company achieved a profitability of $17 \%$, with fixed costs representing $35 \%$ and variable costs $48 \%$ of gross revenue, as shown in the table below.

Table 3. Financial results of Company Alfa

\begin{tabular}{lccccc}
\hline \multicolumn{1}{c}{ Description } & $\mathbf{2 0 1 5}$ & $\mathbf{2 0 1 6}$ & $\mathbf{2 0 1 7}$ & $\mathbf{2 0 1 8}$ & $\mathbf{2 0 1 9}$ \\
\hline$(=)$ Net Sales & $\mathrm{R} \$ 1,928,415$ & $\mathrm{R} \$ 2,312,500$ & $\mathrm{R} \$ 2,532,600$ & $\mathrm{R} \$ 2,750,650$ & $\mathrm{R} \$ 3,272,160$ \\
\hline Quantity produced (units) & 85,240 & 92,500 & 93,800 & 94,850 & 96,240 \\
\hline$(-)$ Variable costs & $\mathrm{R} \$ 925,639$ & $\mathrm{R} \$ 1,202,500$ & $\mathrm{R} \$ 1,342,278$ & $\mathrm{R} \$ 1,540,364$ & $\mathrm{R} \$ 1,897,853$ \\
\hline$(-)$ Fixed costs & $\mathrm{R} \$ 674,945$ & $\mathrm{R} \$ 508.750$ & $\mathrm{R} \$ 547,042$ & $\mathrm{R} \$ 687,663$ & $\mathrm{R} \$ 850,762$ \\
\hline$(=)$ Operating results & $\mathrm{R} \$ 327,831$ & $\mathrm{R} \$ 601,250$ & $\mathrm{R} \$ 643,280$ & $\mathrm{R} \$ 522,624$ & $\mathrm{R} \$ 523,546$ \\
\hline (\%) Profitability & $17 \%$ & $26 \%$ & $25 \%$ & $19 \%$ & $16 \%$ \\
\hline Source Resear
\end{tabular}

Source: Research data, based on Neves and Martins (2012), adapted.

As can be seen in Table 3 above, in 2016, fixed costs represented 22\% (13\% less than in 2016) and variable costs represented $52 \%$ (4\% more than in the previous year) and profitability grew by $17 \%$ to $26 \%$. In 2017 , fixed costs remained at $22 \%$ and variable costs rose to $53 \%$, resulting in a profitability of $25 \%$. However, in 2018 fixed costs grew to $25 \%$ (3\% more than in 2017) and in 2019 they rose to $26 \%$ (in the same years variable costs rose to $56 \%$ and $58 \%$ respectively). In 2018, profitability dropped to 19\% (6\% less than in 2017) and in 2019 profitability decreased even further, going to $16 \%$. It is noteworthy that, according to the documents examined, in the last two years the company maintained and even increased the outsourcing of its activities, however, profitability decreased by $10 \%$ from 2017 to 2019 . 
To understand the reasons for the increase in fixed costs and the consequent cause of the drop-in profitability, we sought to examine the structure of the decision-making process in outsourcing. The purpose was to verify whether the model contributed in any way to these events. After receiving the completed questionnaires and analysing the documentation presented, the following results were found:

Table 4. Efficiency index of the structure of the decision-making process in outsourcing in Company Alfa

\begin{tabular}{|c|c|c|c|c|c|c|c|c|}
\hline \multirow[b]{2}{*}{ Description of the Assessed Rate } & \multirow[b]{2}{*}{$\mathbf{A}$} & \multirow[b]{2}{*}{ D } & \multirow[b]{2}{*}{$\mathbf{V}$} & \multirow[b]{2}{*}{$\mathbf{R}$} & \multirow[b]{2}{*}{$\mathbf{i E}$} & \multirow[b]{2}{*}{$\mathbf{C i E}$} & \multicolumn{2}{|r|}{ PINRF } \\
\hline & & & & & & & $\%$ & $\underset{n}{\text { Classificatio }}$ \\
\hline Rate of infrastructure preliminary study efficiency. & 1 & 1 & 3 & 2 & 1,25 & $\begin{array}{l}\text { Very } \\
\text { low }\end{array}$ & $80 \%$ & VERY HIGH \\
\hline $\begin{array}{l}\text { Rate of outsourcing process cost identification } \\
\text { efficiency. }\end{array}$ & 1 & 1 & 2 & 2 & 1,25 & $\begin{array}{l}\text { Very } \\
\text { low }\end{array}$ & $80 \%$ & VERY HIGH \\
\hline $\begin{array}{l}\text { Rate of problem solving and alternative } \\
\text { construction efficiency }\end{array}$ & 3 & 1 & 2 & 2 & 1,50 & $\begin{array}{l}\text { Very } \\
\text { low }\end{array}$ & $67 \%$ & VERY HIGH \\
\hline $\begin{array}{l}\text { Rate of problem identification and diagnosis } \\
\text { efficiency. }\end{array}$ & 2 & 1 & 2 & 2 & 1,75 & Low & $57 \%$ & HIGH \\
\hline $\begin{array}{l}\text { Rate of process efficiency of choosing the best } \\
\text { alternative. }\end{array}$ & 1 & 2 & 2 & 2 & 1,75 & Low & $57 \%$ & HIGH \\
\hline $\begin{array}{l}\text { Rate of efficiency of vertical and horizontal } \\
\text { options communication. }\end{array}$ & 2 & 2 & 2 & 2 & 1,75 & Low & $57 \%$ & HIGH \\
\hline $\begin{array}{l}\text { Rate of mapping efficiency of internal and external } \\
\text { processes }\end{array}$ & 2 & 3 & 2 & 2 & 1,75 & Low & $57 \%$ & HIGH \\
\hline $\begin{array}{l}\text { Rate of identification efficiency of internal and } \\
\text { external benefits }\end{array}$ & 1 & 2 & 1 & 1 & 1,75 & Low & $57 \%$ & HIGH \\
\hline $\begin{array}{l}\text { Rate of the relationship efficiency between the } \\
\text { selection of partners and the desired competencies. }\end{array}$ & 2 & 1 & 1 & 1 & 1,75 & Low & $57 \%$ & HIGH \\
\hline $\begin{array}{l}\text { Rate of analysis efficiency and evaluation of } \\
\text { alternatives. }\end{array}$ & 2 & 2 & 1 & 2 & 2,00 & Low & $50 \%$ & HIGH \\
\hline Rate of strategic decision efficiency. & 2 & 2 & 2 & 1 & 2,00 & Low & $50 \%$ & HIGH \\
\hline Rate of long-term strategic thinking efficiency. & 2 & 1 & 2 & 2 & 2,25 & Low & $44 \%$ & HIGH \\
\hline Rate of efficiency of adequacy of the service level. & 2 & 3 & 2 & 2 & 2,25 & Low & $44 \%$ & HIGH \\
\hline $\begin{array}{l}\text { Rate of efficiency in defining areas subject to } \\
\text { subcontracting. }\end{array}$ & 4 & 3 & 2 & 2 & 2,75 & Low & $36 \%$ & MEDIUM \\
\hline Total performance & 1,93 & 1,79 & 1,86 & 1,79 & 1,00 & $\begin{array}{l}\text { Very } \\
\text { Low }\end{array}$ & $100 \%$ & VERY HIGH \\
\hline
\end{tabular}

Source: Constructed by the authors from the literature used in the research.

Label: A - Application; D - Documentation; V - Documentation validation; R - Results; iE: Efficiency Rate; CiE Classification of the Efficiency Rate; e PINRF - Potential for negative impact on financial results.

According to the Table 4, it was found that the rates corresponding to the efficiency of the previous study of the infrastructure and the identification of the costs of the outsourcing process had the worst performance with an efficiency rate of only 1.25 points, considered as "very low", which generates a "very high" impact on the company's financial results. The same level obtained by the study of the efficiency of construction of problem solving and 
alternatives, which, despite having obtained 1.50 points, was obtained a rate of negative impact on the results of $67 \%$ considered as "very high".

Regarding the analysis of efficiency related to the identification and diagnosis of problems; process of choosing the best alternative; communication of vertical and horizontal options; mapping of internal and external processes; identification of internal and external benefits; and efficiency of the relationship between the selection of partners and the desired skills, there was a rate of 1.75 points, considered low, with a margin of negative impact on financial results in the order of 57\%, considered high. On the same level are the efficiency of analysis and evaluation of alternatives ( 2.00 points); strategic decision efficiency ( 2.00 points); efficiency of long-term strategic thinking ( 2.25 points); and efficiency of service level adequacy (2.25 points). These four items were also in the range of performance considered low, with the potential to negatively impact financial results classified as "high".

The best performance was in the item relating to the efficiency of defining areas subject to outsourcing, which reached 2.75 points, classified as medium performance, with a potential negative impact on financial results of $36 \%$, considered average.

Overall, according to the consolidated data in Table 4, it can be seen that, both the application of the decision-making evaluation criteria and the analysed documentation, its validation and the results received the classification of the efficiency rate as "very low" in the efficiency rate, with the potential to negatively impact financial results being considered "very high".

Given the above, it was found that the structure of the decision-making process of Company Alpha to define the application of outsourcing is very precarious, which can cause damage to the entity's assets, such as financial losses and unforeseen expenses, impacting the increase in fixed costs, influencing the operating result and reducing business profitability.

In a broader analysis, considering the financial results of the Company Alpha in the period 2015 to 2019 (Table 3), it was found that, even keeping and expanding outsourced operations and the consequent transformation of a portion of fixed to variable costs in the years 2018 and 2019, the company showed a loss of profitability in these financial years, that is, in 2018 the profitability decreased from 25\% to 19\% compared to 2017. In 2019 the profitability decreased even further, from 19\% to 16\%. Thus, contrary to what Neves and Martins (2012) suggest, in 2018 and 2019 the percentage of fixed costs rose to $25 \%$ and $26 \%$ respectively, and it is not possible to maintain the percentage of fixed costs at the average level for the years of 2016 and 2017, which corresponds to 22\%, although outsourcing and the transfer of fixed to variable costs were maintained.

When analysing the Profit and Loses (P\&L) of Company Alpha, it was verified the appearance in 2018 and 2019 of legal expenses and labour agreements with personnel arising from claims with workers of outsourced companies in the courts, expenses that did not exist in the years of 2015 to 2017. Such expenses were recorded as fixed costs simply because these expenses are not linked to production, as prescribed by Martins (2010).

Thus, it is assumed that these expenses impacted the expenses of 2018 and 2019, causing the loss of profitability and a reduction in operating income. However, to ensure this, we sought to understand how these costs impacted the entity's financial results. For this, the company's documentation was analysed, and the following situations were found:

a) Little evidence was found on the procedures related to the correct identification and diagnosis of problems;

b) There are practically no procedures for the construction of problem solving and alternatives;

c) As a result, the analysis and evaluation of alternatives, as well as the process of choosing the best alternative, were hampered;

d) The communication of vertical and horizontal options is quite deficient, it was found that most communications occur verbally, which facilitates possible distortions on the objectives of communication;

e) The strategic decision is heavily concentrated on a small group of people (usually at the top of the command). Such centralization undermines long-term strategic thinking;

f) No evidence was found on the previous infrastructure study; thus, it is not known whether the outsourcing process actually represents the best alternative to be followed (considering the other aspects, in addition to the economic ones);

g) No studies or models adopted to identify the costs of the outsourcing process were detected. It was noted that this task was fully transferred to the Accounting Office, which does not report on the matter; 
h) The company does not adopt adequate procedures for mapping internal and external processes;

i) There are no records identifying the internal and external benefits of outsourcing. There are positive statements on the subject, but the absence of records makes this process vulnerable;

j) The relationship between partner selection and desired competencies is unclear. Most are verbal and do not offer conditions to control these procedures;

k) The efficiency of service level adequacy is not measured (recorded); and

1) The definition of the areas subject to outsourcing was carried out considering only the economic aspects, leaving aside questions about structure, personnel, the environment and other matters relevant to the theme.

After these analyses, it was found that most of the lawsuits are due to poorly prepared contracts; lack of previous studies; poor communication; absence of a capacity building and training plan; and failure in the process of monitoring and controlling operations and results. For these reasons, it is understood that the deficiencies in the decision-making process that subsidized the implementation of outsourcing at Company Alfa contributed to generate negative impacts on the entity's financial results. These impacts can be represented by the amounts spent to cover legal expenses with outsourced personnel in 2018 and 2019, as shown in the table below:

Table 5. Legal expenses with personnel: direct and outsourced 2018/2019 in Company Alfa

\begin{tabular}{lccc}
\hline \multicolumn{1}{c}{ Description } & $\mathbf{2 0 1 8}$ & $\mathbf{2 0 1 9}$ & $\begin{array}{c}\text { Total } \\
\text { accumulated }\end{array}$ \\
\hline Total legal expenses with personnel & $\mathrm{R} \$ 82,520$ & $\mathrm{R} \$ 130,886$ & $\mathrm{R} \$ 213,406$ \\
\hline Legal expenses with outsourced personnel & $\mathrm{R} \$ 79,200$ & $\mathrm{R} \$ 128,910$ & $\mathrm{R} \$ 208,110$ \\
\hline Percentage in relation to legal expenses with personnel & $96 \%$ & $98 \%$ & $98 \%$ \\
\hline Percentage of sales revenue & $2,88 \%$ & $3,94 \%$ & $3,46 \%$ \\
\hline
\end{tabular}

Source: Profit and Loses for the Year - P\&L 2018/2019 Company Alpha.

According to the data in Table 5, the total expenditure on legal expenses with personnel in 2018 was $\mathrm{R} \$ 82,520$ and in 2019 it was $\mathrm{R} \$ 130,886$. Of this amount, the legal expense with outsourced personnel alone was $\mathrm{R} \$ 79,200$ in 2018 and $\mathrm{R} \$ 128,910$ in 2019. In 2018, the legal expense with outsourced personnel represented $2.88 \%$ of the total revenue reported in Table 3. in 2019 this percentage rose to 3.94\%. The total accumulated expense is $\mathrm{R} \$ 208,110$, which represents $3.46 \%$ of the revenues for the period 2018 and 2019.

To identify the dimension of these impacts, a simulation was carried out extracting the amounts identified as legal expenses with outsourced personnel in the years 2018 and 2019. The results of this test can be seen in the following Tables:

Table 6. Company Alpha financial results simulation (extracting legal expenses with outsourced personnel)

\begin{tabular}{lccccc}
\hline \multicolumn{1}{c}{ Description } & $\mathbf{2 0 1 5}$ & $\mathbf{2 0 1 6}$ & $\mathbf{2 0 1 7}$ & $\mathbf{2 0 1 8}$ & $\mathbf{2 0 1 9}$ \\
\hline (=) Net Sales & $\mathrm{R} \$ 1,928,415$ & $\mathrm{R} \$ 2,312,500$ & $\mathrm{R} \$ 2,532,600$ & $\mathrm{R} \$ 2,750,650$ & $\mathrm{R} \$ 3,272,160$ \\
\hline Quantity produced (units) & 85,240 & 92,500 & 93,800 & 94,850 & 96,240 \\
\hline (-) Variable costs & $\mathrm{R} \$ 925,639$ & $\mathrm{R} \$ 1,202,500$ & $\mathrm{R} \$ 1,342,278$ & $\mathrm{R} \$ 1,540,364$ & $\mathrm{R} \$ 1,897,853$ \\
\hline (-) Fixed costs & $\mathrm{R} \$ 674,945$ & $\mathrm{R} \$ 508,750$ & $\mathrm{R} \$ 547,042$ & $\mathrm{R} \$ 608,463$ & $\mathrm{R} \$ 721,852$ \\
\hline (=) Operating results & $\mathrm{R} \$ 327,831$ & $\mathrm{R} \$ 601,250$ & $\mathrm{R} \$ 643,280$ & $\mathrm{R} \$ 601,824$ & $\mathrm{R} \$ 652,456$ \\
\hline (\%) Profitability & $17 \%$ & $26 \%$ & $25 \%$ & $22 \%$ & $20 \%$ \\
\hline
\end{tabular}

Source: Constructed by the authors from research data, based on Neves and Martins (2012), adapted. 
Table 7. Comparison of the impact on the operating results of the Company Alfa

\begin{tabular}{|c|c|c|c|c|c|}
\hline Comparison & 2015 & 2016 & 2017 & 2018 & 2019 \\
\hline $\begin{array}{l}\text { (=) Actual operating results } \\
\text { (Table 3) }\end{array}$ & $\mathrm{R} \$ 327,831$ & $\mathrm{R} \$ 601,250$ & $\mathrm{R} \$ 643,280$ & $\mathrm{R} \$ 522,624$ & $\mathrm{R} \$ 523,546$ \\
\hline $\begin{array}{l}(=) \text { Simulated } \\
\text { result (Table 6) }\end{array}$ & $\mathrm{R} \$ 327,831$ & $\mathrm{R} \$ 601,250$ & $\mathrm{R} \$ 643,280$ & $\mathrm{R} \$ 601,824$ & $\mathrm{R} \$ 652,456$ \\
\hline Difference & - & - & - & $\mathrm{R} \$ 79,200$ & $\mathrm{R} \$ 128,910$ \\
\hline $\begin{array}{l}\text { (\%) Actual profitability } \\
\text { (Table 3) }\end{array}$ & $17 \%$ & $26 \%$ & $25 \%$ & $19 \%$ & $16 \%$ \\
\hline $\begin{array}{l}\text { (\%) Simulated profitability } \\
\text { (Table 6) }\end{array}$ & $17 \%$ & $26 \%$ & $25 \%$ & $22 \%$ & $20 \%$ \\
\hline Difference & $0 \%$ & $0 \%$ & $0 \%$ & $3 \%$ & $4 \%$ \\
\hline
\end{tabular}

Source: Constructed by the authors from research data, based on Neves and Martins (2012), adapted.

Comparing the simulated result in Table 6 with the actual result in Table 3, when extracting from the fixed costs the amounts corresponding to legal expenses with outsourced personnel, it can be seen that in 2018 there is a profitability gain of $3 \%$ corresponding to the value of $\mathrm{R} \$ 79,200$. In 2019 , the profitability gain would be around $4 \%$ corresponding to the amount of $\mathrm{R} \$ 128,910$. In this way, the value of accumulated losses in the period (2018/2019) is confirmed, which reach a total of $\mathrm{R} \$ 208,110$.

In view of the facts presented, it can be concluded that the competitive cost advantage obtained by Company Alfa from the implementation of outsourcing had a negative impact on the entity's financial operating result. From what was seen in this work, these expenses may have occurred due to the opportunism of outsourced agents who, taking advantage of the gaps left by a flawed decision-making process in relation to the implementation of outsourcing, used artifices to subtract advantages through the legal action of the company, which resulted in the generation of transaction costs (FARINA; AZEVEDO; SAES, 1997).

Thus, despite the positive aspects observed in the operating results, which shows a growth in profitability from $\mathrm{R} \$ 327,831$ in 2017 to $\mathrm{R} \$ 523,546$ in 2019 (see Table 3), there is a drop-in profitability in the business, the from the year 2018 .

It is noteworthy that the research found that this transaction cost is not perfectly perceived by the company's managers, a fact that highlights the failure in the decision-making process and monitoring management, as evidenced in the results shown so far. It was noticed that the company's managers focused on the good performance of operating results, leaving aside the monitoring of profitability, which, in turn, could be more favourable if these transaction costs arising from the opportunism of outsourced agents could have been avoided or at least minimized.

\section{Conclusion}

The problem faced in this work is related to business efficiency with regard to the ability to use managerial tools that have been proven to have their value recognized by the literature on the subject. Specifically, we sought to answer how the decision-making process model used to decide on the implementation of outsourcing in the company affected the competitive advantage in costs obtained by the organization after the implementation of outsourcing. Therefore, the financial results obtained by the company in the period from 2015 to 2019 were analyzed in order to know if there were competitive advantages in costs arising from the decision to implement outsourcing. Furthermore, studies were carried out on the structure of the decision-making process adopted by the entity, to identify the level of efficiency of this model in the implementation of outsourcing, and finally, the impacts generated on these advantages due to the degree of efficiency of the application of the tool were verified.

In order to achieve the research objectives, the mathematical model presented in chapter three of this work was built, where 14 (fourteen) indicators were established to analyze the efficiency of the decision-making process. For the formation of the efficiency rate, 4 (four) indicators were adopted and to classify the level of efficiency, 5 (five) five criteria were established, all presented in the topic that deals with the methodology of this research. 
The results showed that there is sufficient evidence to conclude that the low level of efficiency in the decision-making structure contributed to the high financial impact on Company Alpha and, consequently, to the negative impact on competitiveness acquired through the implementation of outsourcing in this entity, the which caused him financial losses represented by losses in operating income and reduction in profitability.

It is noteworthy that the effects that negatively impacted the company's operating result and profitability arise from legal expenses and labor agreements with personnel arising from claims with workers from outsourced companies in court, since these expenses were recorded as fixed costs because they did not are linked to production. It was found that these expenses occurred due to the opportunism of outsourced agents who, taking advantage of the gaps left by a flawed outsourcing decision-making process, used artifices to subtract advantages through the company's lawsuit, which resulted in cost generation transaction.

Another interesting detail was noticed during the research was the low perception, by managers, of the extra costs arising from these legal expenses. This fact is reputed to the low level of efficiency in managing the outsourcing decision-making process. Apparently, the focus of managers is concentrated only on the positive results related to sales and revenue growth. Thus, it was noted that, in the view of these managers, as long as the company maintains growth in production and revenue, the rest is fine. This situation shows that there is no complete view by managers regarding the opportunity costs generated from the risks that the company runs due to the inefficiency found in the management of the decision-making process.

It is therefore concluded that the investigated company achieved a competitive advantage in costs obtained from the implementation of the outsourcing model in its production operations, notably through the outsourcing of middle and end activities, through the transformation of fixed costs into variable costs. However, given the low efficiency in the decision-making process, these advantages suffered negative impacts on its financial results, culminating in a loss in profitability and a decrease in operating results, whose value reached the amount of $R \$ 208,110$ in 2018 and 2019, as shown in this work.

Finally, it is noteworthy that the inadequate structuring of the decision-making process does not, by itself, represent the determining reason for the occurrence of the damage pointed out in this work, so it is recommended that, for further research, organizational studies be deepened with a view to identify other management parameters that may affect the performance of companies. However, given what was found in this work, it is possible to infer that the decision-making system plays a fundamental role in minimizing or maximizing the negative effects on the company's finances. Thus, its adaptation to the best techniques is an essential condition for maintaining and expanding the competitive advantages in costs obtained from the implementation of the outsourcing process in the organization.

\section{References}

Banakouche, R. (2010, Sep./Dec.). Decision-making Process, Organizational Objectives and Staff Interests: theoretical elements of an incremental approach. Journal of Administration Sciences, 12(28), 147-170.

Bertoncini, C., Brito, A., Leme, E., Silva, I., Silva, T. F. da., \& Perri, R. A. (2013). Decision-making process: decision making. FAEF Journal, 5(3), 8-34. Retrieved 20 March 2020, from http://faef.revista.inf.br/imagens_arquivos/arquivos_destaque/QjxDDqGcS5r3dHL_2013-5-3-12-8-34.pdf

Farina, E. M. M. Q., Azevedo, P. F. A., \& Saes, M. S. M. (1997). Competitiveness: market, state and organizations. São Paulo: Singular.

Franz, L. S., \& Kramer, M. W. (2010). The Dimensios of Decision: a conceptual and empirical investigation. In Nutt, P. C., \& Wilson, D. C. (Eds.), Handbook of -Decision Making (pp. 517-540). West Sussex: Wiley.

Freitas, I. D. de., Almeida, C. M. F., \& Oliveira, O. V. de. (2017). Accounting: outsource or have it in the company? Study with companies in the clothing segment. Extension, Teaching and Scientific Initiation Meeting (EEDIC), Unicatólica, 4(1).

Gil, A. C. (2007). Methods and techniques of social research (5th ed.). São Paulo: Atlas.

Junior, J. B. de C., \& Pires, S. R. I. (2017). Systematization of Logistics Outsourcing Implementation through Project Management Practices. Production Management Journal, 24(2), 310-323.

Leone, G. S. (2009). Costs, Planning, Implementation and Control. São Paulo: Atlas.

Martins, E. (2010). Cost accounting (10th ed.). São Paulo: Atlas.

Maximiano, A. C. A. (2009). Introduction to Administration. Ed. Compacta. São Paulo: Atlas. 
Mcivor, R. (2005). The outsourcing process: strategies for evaluation and management. Cambridge: Cambridge $\begin{array}{llllll}\text { University } & \text { Press. } & \text { Retrieved } & 24 & \text { Feb. } & \text { 2020, }\end{array}$ https://www.cambridge.org/core/books/outsourcing-process/F5127314A940C70C68A7FE5285F7DE68

Moritz, G. de O., \& Pereira, M. F. (2006). Decision making process. Florianópolis: SEAD/UFSC.

Neves, H. de C., \& Martins, P. do C. (2012, November). Learn why Outsourcing improves business profitability. Food Ingredients Brazil Magazine, (23), 50-52.

Porter, M. E. (2005). Competitive strategy. Rio de Janeiro: Campus.

Porto, G. S. (2004, Jul./Sep.). Characteristics of the decision-making process in company-university cooperation. RAC - Journal of Contemporary Administration, 8(3), 29-52. Retrieved 19 March 2020, from http://www.scielo.br/pdf/rac/v8n3/v8n3a03.pdf

Rocco, N. Accounting: outsource or have it in the company? IG Economy. Retrieved 20 Oct. 2020, from http://economia.ig.com.br/financas/seunegocio/contabilidade-terceirizar-ou-ternaempresa/n1237617847429.htm 1

Sa, M. P., Bomtempo, J. V., \& Quental, C. (1998, May/Aug.). Outsourcing in the final processing of the pharmaceutical and veterinary industries. Journal of Contemporary Administration, 2(2).

Simon, H. (1980). The rationality of the decision-making process in companies. Rio de Janeiro: Multipl, 1(1).

Uris, A. (1989). The executive table book. São Paulo, Editora Pioneira.

Valença, M. C. de A., \& Barbosa, A. C. Q. (2002, Jan./Apr.). Outsourcing and its impacts: a study in large organizations in Minas Gerais. Journal of Contemporary Administration, 6(1), Curitiba.

Vasconcelos, F. C., \& Cyrino, Á. B. (2000, Oct./Dec.). Competitive Advantage: current theoretical models and the convergence between strategy and organizational theory. RAE - Business Administration Journal, 40(4), 20-37. Retrieved 28 March 2020, from https://www.scielo.br/pdf/rae/v40n4/v40n4a03.pdf

Yin, R. K. (2005). Case study: planning and methods (3rd ed.). Porto Alegre: Bookman.

\section{Copyrights}

Copyright for this article is retained by the author(s), with first publication rights granted to the journal.

This is an open-access article distributed under the terms and conditions of the Creative Commons Attribution license (http://creativecommons.org/licenses/by/4.0/). 